\title{
Transfer of Teichococcus ludipueritiae and Muricoccus roseus to the genus Roseomonas, as Roseomonas ludipueritiae comb. nov. and Roseomonas rosea comb. nov., respectively, and emended description of the genus Roseomonas
}

Correspondence
Antonio Ventosa
ventosa@us.es

The alphaproteobacterial genus Roseomonas includes a number of species which are characterized by their typical pink pigmentation, oxidative metabolism and coccoid-rod shape, appearing in pairs or short chains (Rihs et al., 1993,

$16 \mathrm{~S}$ rRNA gene sequence-based maximum-parsimony and maximumlikelihood trees, fatty acid profiles of various strains and 2D TLC of polar lipids of $R$. gilardii subsp. gilardii CIP $104026^{\top}$ are available as supplementary material with the online version of this paper.

\author{
Cristina Sánchez-Porro, ${ }^{1}$ Virginia Gallego, ${ }^{1}$ Hans-Jürgen Busse, ${ }^{2}$ \\ Peter Kämpfer ${ }^{3}$ and Antonio Ventosa ${ }^{1}$
}
${ }^{1}$ Department of Microbiology and Parasitology, Faculty of Pharmacy, University of Sevilla, E-41012 Sevilla, Spain
${ }^{2}$ Institut für Bakteriologie, Mykologie und Hygiene, Veterinärmedizinische Universität, A-1210 Wien, Austria
${ }^{3}$ Institute for Applied Microbiology, Justus-Liebig-Universität Giessen, IFZ, Heinrich-Buff-Ring 26- 32, D-35392 Giessen, Germany

\begin{abstract}
Phylogenetic analyses based on 16S rRNA gene sequences revealed that Teichococcus Iudipueritiae and Muricoccus roseus are closely related to the species of the genus Roseomonas. The type strain of Teichococcus ludipueritiae, $170 / 96^{\top}$, exhibited $16 \mathrm{~S}$ rRNA gene sequence similarity levels of $96.4 \%$ to Roseomonas cervicalis ATCC $49957^{\top}, 95.0 \%$ to Roseomonas aquatica TR53 ${ }^{\top}, 94.5 \%$ to Muricoccus roseus $173 / 96^{\top}, 93.4 \%$ to Roseomonas mucosa ATCC BAA $-692^{\top}$ and $93.5 \%$ to Roseomonas gilardii subsp. gilardii ATCC $49956^{\top}$, while Muricoccus roseus $173 / 96^{\top}$ showed $16 \mathrm{~S}$ rRNA gene sequence similarity values of $95.7 \%$ to $R$. mucosa ATCC BAA $-692^{\top}, 95.7 \%$ to $R$. aquatica TR53 ${ }^{\top}$ and $95.3 \%$ to $R$. gilardii subsp. gilardii ATCC $49956^{\top}$ and $R$. gilardii subsp. rosea ATCC BAA-691 ${ }^{\top}$. Different phylogenetic analysis methods (neighbour-joining, maximum-likelihood and maximum-parsimony) confirmed that both species are within the Roseomonas branch. Neither polyamine patterns (spermidine predominant) nor major characteristics in the polar lipid profiles distinguished the two species from representatives of the genus Roseomonas. The fatty acid composition of the two species exhibited alphaproteobacterial characteristics but, like Roseomonas species, they also showed considerable amounts of the rarely encountered $\mathrm{C}_{18: 1} 2-\mathrm{OH}$. On the other hand, they showed some phenotypic differences, but their features are compatible with the transfer of these two species to the genus Roseomonas. We propose the reclassification of Teichococcus ludipueritiae and Muricoccus roseus as Roseomonas ludipueritiae comb. nov. (type strain $170 / 96^{\top}=\mathrm{CIP} 107418^{\top}=\mathrm{DSM} 14915^{\top}$ ) and Roseomonas rosea comb. nov. (type strain $173 / 96^{\top}=\mathrm{CIP} 107419^{\top}=\mathrm{DSM} 14916^{\top}$ ), respectively. Emended descriptions of the genus Roseomonas and the species Roseomonas gilardii (and its subspecies Roseomonas gilardii subsp. gilardii and Roseomonas gilardii subsp. rosea), Roseomonas aquatica, Roseomonas cervicalis, Roseomonas mucosa and Roseomonas lacus are provided.
\end{abstract}

1998). At the time of writing, the genus comprised six recognized species: Roseomonas gilardii (type species, with two subspecies, $R$. gilardii subsp. gilardii and $R$. gilardii subsp. rosea) (Rihs et al., 1993, 1998; Han et al., 2003), Roseomonas cervicalis (Rihs et al., 1993, 1998), Roseomonas mucosa (Han et al., 2003), Roseomonas lacus (Jiang et al., 2006), Roseomonas aquatica (Gallego et al., 2006) and Roseomonas terrae (Yoon et al., 2007). Another species 
originally described as Roseomonas fauriae (Rihs et al., 1993, 1998) has been proposed to be a later heterotypic synonym of Azospirillum brasilense (Helsel et al., 2006). The genera Teichococcus and Muricoccus were proposed by Kämpfer et al. (2003) and each include a single species: Teichococcus ludipueritiae and Muricoccus roseus. These species are short, Gram-negative rods, strictly aerobic and able to use sugars, organic acids and amino acids as carbon sources. They are characterized by the presence of straightchain fatty acids with $\mathrm{C}_{18: 1} 2-\mathrm{OH}$ (for Teichococcus) and $\mathrm{C}_{18: 1} 2-\mathrm{OH}$ and $\mathrm{C}_{18: 0} 3-\mathrm{OH}$ (for Muricoccus) (Kämpfer et al. 2003).

During the course of a previous study (Gallego et al., 2006), we determined that the species $T$. ludipueritiae and $M$. roseus were phylogenetically closely related to the species of the genus Roseomonas. In this study, we have compared these two species with six Roseomonas species. Phenotypic and phylogenetic data suggest that T. ludipueritiae and $M$. roseus should be placed within the genus Roseomonas. We also amend the description of the genus and five species of Roseomonas, including new data on their nutritional capabilities, polyamines and polar lipid composition.

The following strains were used in this study: T. ludipueritiae DSM $14915^{\mathrm{T}}, M$. roseus DSM $14916^{\mathrm{T}}$, R. gilardii subsp. gilardii CIP $104026^{\mathrm{T}}$, R. gilardii subsp. rosea CIP $108267^{\mathrm{T}}, R$. aquatica TR53 ${ }^{\mathrm{T}}$, R. cervicalis CIP $104027^{\mathrm{T}}$, R. lacus CIP $109168^{\mathrm{T}}$ and $R$. mucosa CIP $108268^{\mathrm{T}}$. They were routinely cultured on tryptic soy agar (TSA) at $30{ }^{\circ} \mathrm{C}$ for $48 \mathrm{~h}$.

Tests for acid production from carbohydrates and enzymes were carried out using API 20 NE, API ID 32E and API ZYM strips (bioMérieux) inoculated according to the manufacturer's instructions and incubated at $30{ }^{\circ} \mathrm{C}$. The utilization of sugars and other compounds was determined on API $50 \mathrm{CH}$ strips (bioMérieux) inoculated as described by Kersters et al. (1984). Table 1 shows the results of these tests.

The 16S rRNA gene sequences of T. ludipueritiae $170 / 96^{\mathrm{T}}$ and $M$. roseus $173 / 96^{\mathrm{T}}$ were determined previously (Kämpfer et al., 2003); the identification of phylogenetic neighbours and calculation of pairwise 16S rRNA gene sequence similarity were achieved using the EzTaxon server (http://www.eztaxon.org/; Chun et al., 2007). Sequence analysis was carried out using the ARB program package (Ludwig et al., 2004). Following the recommendations of Ludwig et al. (1998), alternative treeing methods (neighbour-joining, maximum-parsimony and maximum-likelihood) were used. A comparison using 16S rRNA gene sequences from databases revealed that the 16S rRNA gene sequences of T. ludipueritiae $170 / 96^{\mathrm{T}}$ and M. roseus $173 / 96^{\mathrm{T}}$ display a high degree of similarity to certain Roseomonas species. The closest relatives of T. ludipueritiae $170 / 96^{\mathrm{T}}$ are $R$. cervicalis ATCC $49957^{\mathrm{T}}, R$. aquatica TR $53^{\mathrm{T}}$, M. roseus $173 / 96^{\mathrm{T}}$, R. mucosa ATCC BAA- $692^{\mathrm{T}}$ and R. gilardii subsp. gilardii ATCC $49956^{\mathrm{T}}$, with 96.4, 95.0, 94.5, 93.4 and $93.5 \%$ sequence similarity, respectively. The closest relatives of $M$. roseus $173 / 96^{\mathrm{T}}$ are $R$. mucosa ATCC BAA$692^{\mathrm{T}}, R$. aquatica TR53 ${ }^{\mathrm{T}}, R$. gilardii subsp. gilardii ATCC
$49956^{\mathrm{T}}$ and $R$. gilardii subsp. rosea ATCC BAA-691 ${ }^{\mathrm{T}}$, with 95.7, 95.7, 95.3 and $95.3 \%$ sequence similarity, respectively. The phylogenetic tree obtained by the neighbourjoining method shows that T. ludipueritiae $170 / 96^{\mathrm{T}}$ and $M$. roseus $173 / 96^{\mathrm{T}}$ fall within a cluster constituted by the species of Roseomonas (Fig. 1). The tree topology was similar when two other algorithms (maximum-parsimony and maximum-likelihood) were used (Supplementary Fig. S1, available in IJSEM Online).

Fatty acids were analysed by gas chromatography as described in detail by Kämpfer \& Kroppenstedt (1996). Cells were cultured on TSA at pH 7.0, $28{ }^{\circ} \mathrm{C}$ for 24 h. Fatty acid profiles for the strains studied are shown in Supplementary Table S1. The predominant fatty acids were $\mathrm{C}_{18: 1} \omega 7 c$, in addition to $\mathrm{C}_{16: 0}$ and $\mathrm{C}_{16: 1} \omega 7 c /$ iso- $\mathrm{C}_{15: 0}$ $2-\mathrm{OH}$ (summed feature 3 ). The data were in congruence with those published previously (Kämpfer et al., 2003; Gallego et al., 2006), with the exception of the fatty acid profile published for $R$. lacus by Jiang et al. (2006), who found major amounts of iso- and anteiso-branched branched fatty acids, which are very atypical for alphaproteobacteria of the Roseomonas group and may have been reported in error. In our study, we found a profile typical of Roseomonas for R. lacus CIP $109168^{\mathrm{T}}$ (Supplementary Table S1). All type strains shown in Supplementary Table S1 also showed the production of the hydroxylated fatty acid $\mathrm{C}_{18: 1} 2-\mathrm{OH}$. The fatty acid $\mathrm{C}_{18: 0} 3-\mathrm{OH}$ was produced only by $M$. roseus. This was already demonstrated in the study of Kämpfer et al. (2003). It is also interesting to note that $\mathrm{C}_{19: 0}$ cyclo $\omega 8 c$ was not shown for $M$. roseus, $R$. aquatica or $R$. cervicalis, whereas this fatty acid was found in different amounts in all other type strains of the tested species. Hence, the fatty acid profiles are very useful for differentiation at the species level.

For the determination of polyamine patterns and polar lipids, strains were grown on $3.3 \times$ PYE medium $(1.0 \%$ peptone from casein, $1.0 \%$ yeast extract, $\mathrm{pH} 7.2)$ at $28{ }^{\circ} \mathrm{C}$ with the exception of $R$. aquatica TR $53^{\mathrm{T}}$, which was grown on PYE medium ( $0.3 \%$ peptone from casein, 0.3 . \% yeast extract, $\mathrm{pH}$ 7.2) at $28{ }^{\circ} \mathrm{C}$. Polyamines were extracted and analysed as described previously (Busse \& Auling, 1988; Stolz et al., 2007). Analysis of T. ludipueritiae DSM $14915^{\mathrm{T}}$, M. roseus DSM $14916^{\mathrm{T}}$, R. gilardii subsp. gilardii CIP $104026^{\mathrm{T}}$, R. gilardii subsp. rosea CIP $108267^{\mathrm{T}}, R$. aquatica TR53 ${ }^{\mathrm{T}}$, R. cervicalis CIP $104027^{\mathrm{T}}$, R. lacus CIP $109168^{\mathrm{T}}$ and R. mucosa CIP $108268^{\mathrm{T}}$ revealed homogeneous polyamine patterns, with the predominant compound spermidine [28-45 $\mu \mathrm{mol}$ (g dry weight $\left.)^{-1}\right]$, moderate to minor amounts of putrescine $[0.1-8.1 \mu \mathrm{mol} \text { (g dry weight })^{-1}$ ] and minor amounts of spermine $[0.1-2.5 \mu \mathrm{mol}$ ( $\mathrm{g}$ dry weight $\left.)^{-1}\right]$ and 1,3-diaminopropane $[0.1-0.2 \mu \mathrm{mol}$ (g dry weight $)^{-1}$.

The same set of strains exhibited polar lipid profiles consisting of the major compounds diphosphatidylglycerol, phosphatidylglycerol, phosphatidylethanolamine, phosphatidylcholine and an unidentified aminolipid 
Table 1. Characteristics that differentiate Roseomonas ludipueritiae comb. nov. and Roseomonas rosea comb. nov. from other species of the genus Roseomonas

Strains: 1 , R. ludipueritiae DSM $14915^{\mathrm{T}} ; 2$, R. rosea DSM $14916^{\mathrm{T}} ; 3$, R. gilardii subsp. gilardii CIP $104026^{\mathrm{T}} ; 4$, R. aquatica TR53 ${ }^{\mathrm{T}}, 5$, R. cervicalis CIP $104027^{\mathrm{T}}$, 6, R. gilardii subsp. rosea CIP $108267^{\mathrm{T}} ; 7$, R. lacus CIP $109168^{\mathrm{T}} ; 8$, R. mucosa CIP $108268^{\mathrm{T}}$. +, Positive; -, negative; 土, weak reaction, $\mathrm{v}$, variable; ND, not determined. Data were obtained in this study unless indicated. All strains were positive for alkaline phosphatase, esterase (C4), esterase lipase (C8), lipase, urease, naphthol-AS-BI-phosphohydrolase and L-aspartic acid arylamidase. All strains were negative for utilization of erythritol, dulcitol, methyl $\alpha$-D-mannopyranoside, inulin, glycogen and D-tagatose, activities of valine arylamidase, cystine arylamidase, trypsin, $\alpha$ chymotrypsin, $N$-acetyl- $\beta$-glucosaminidase, $\alpha$-mannosidase, $\alpha$-fucosidase, $\beta$-galactosidase, $\beta$-glucuronidase, $\alpha$-maltosidase and lysine decarboxylase, reduction of nitrate to nitrogen, indole production, fermentation of glucose and acid production from L-arabitol, galacturonate, 5-ketogluconate, mannitol, maltose, adonitol, palatinose, glucose, sucrose, D-arabitol, trehalose, inositol, cellobiose and sorbitol.

\begin{tabular}{|c|c|c|c|c|c|c|c|c|}
\hline Characteristic & 1 & 2 & 3 & 4 & 5 & 6 & 7 & 8 \\
\hline Motility* & - & - & ND & - & + & $\mathrm{V}$ & - & + \\
\hline Optimum growth temperature $\left({ }^{\circ} \mathrm{C}\right)^{*}$ & 30 & 30 & 35 & 28 & 35 & 35 & 30 & 35 \\
\hline Glycerol & + & - & + & - & + & + & + & + \\
\hline D-Arabinose & + & - & + & - & + & - & - & + \\
\hline L-Arabinose & + & - & + & - & + & + & + & + \\
\hline D-Xylose & + & - & + & - & + & + & - & + \\
\hline L-Xylose & + & - & - & - & - & - & - & - \\
\hline D-Adonitol & + & - & - & - & - & - & - & + \\
\hline Methyl $\beta$-D-xylopyranoside & + & - & - & - & - & - & - & - \\
\hline D-Galactose & + & - & + & - & + & + & - & + \\
\hline D-Glucose & + & - & - & - & + & + & - & + \\
\hline Inositol & + & - & - & - & - & - & - & + \\
\hline D-Mannitol & + & - & + & - & - & + & \pm & + \\
\hline D-Sorbitol & + & - & - & - & - & + & \pm & + \\
\hline Methyl $\alpha$-D-glucopyranoside & + & - & - & - & + & - & + & + \\
\hline$N$-Acetylglucosamine & + & - & - & - & + & - & - & + \\
\hline Amygdalin & + & + & + & - & + & + & + & + \\
\hline Arbutin & + & - & - & - & + & + & + & + \\
\hline Aesculin ferric citrate & + & + & + & - & + & + & + & + \\
\hline Salicin & + & - & - & - & + & - & - & - \\
\hline Cellobiose & + & - & + & - & + & + & + & + \\
\hline Maltose & + & + & + & - & + & + & - & + \\
\hline Xylitol & + & - & - & - & \pm & - & - & + \\
\hline Gentiobiose & - & - & - & - & + & - & - & + \\
\hline Turanose & + & - & - & - & + & - & + & + \\
\hline D-Lyxose & + & + & + & - & + & + & - & + \\
\hline D-Fucose & + & - & + & - & - & + & + & + \\
\hline L-Fucose & + & - & - & - & + & + & + & + \\
\hline D- and L-Arabitol & + & - & - & - & - & + & - & + \\
\hline Potassium gluconate & + & - & + & - & + & + & + & + \\
\hline Potassium 2-ketogluconate & + & - & + & - & + & + & + & + \\
\hline Potassium 5-ketogluconate & + & - & - & - & + & - & - & + \\
\hline \multicolumn{9}{|l|}{ Enzyme activities (API ZYM) } \\
\hline Leucine arylamidase & + & - & \pm & + & - & - & - & \pm \\
\hline
\end{tabular}


Table 1. cont.

\begin{tabular}{|c|c|c|c|c|c|c|c|c|}
\hline Characteristic & 1 & 2 & 3 & 4 & 5 & 6 & 7 & 8 \\
\hline Acid phosphatase & - & - & + & + & - & - & + & + \\
\hline$\alpha$-Galactosidase & - & - & + & - & - & + & + & + \\
\hline$\alpha$-Glucosidase & + & - & + & - & - & + & + & + \\
\hline$\beta$-Glucosidase & - & - & \pm & - & - & - & - & - \\
\hline \multicolumn{9}{|l|}{ Other tests (API 20NE and ID 32E) } \\
\hline Reduction of nitrate to nitrite & - & + & - & + & - & - & + & - \\
\hline$\beta$-Glucosidase (aesculin hydrolysis) & + & - & \pm & - & + & \pm & - & + \\
\hline Protease (gelatin hydrolysis) & + & - & \pm & - & + & \pm & - & + \\
\hline Ornithine decarboxylase & + & - & + & - & - & + & + & + \\
\hline Arginine dihydrolase & + & + & - & - & - & - & + & - \\
\hline Malonate utilization & - & - & + & - & - & - & + & - \\
\hline L-Arabinose acidification & + & + & + & + & + & + & - & + \\
\hline Rhamnose acidification & + & - & - & - & + & - & - & - \\
\hline DNA G $+\mathrm{C}$ content $(\mathrm{mol} \%)^{*}$ & 65.8 & 68.9 & $\mathrm{ND}$ & 68.6 & 70.4 & 67.6 & 71.9 & $\mathrm{ND}$ \\
\hline
\end{tabular}

${ }^{\star}$ Data from Kämpfer et al. (2003), Jiang et al. (2006), Han et al. (2003), Rihs et al. (1993) and Gallego et al. (2006).

(AL2) and moderate amounts of another unknown aminolipid (AL1). As an example, the polar lipid profile of R. gilardii subsp. gilardii CIP $104026^{\mathrm{T}}$ is shown in Supplementary Fig. S2. The most striking difference was detected in the polar lipid profile of R. lacus CIP $109168^{\mathrm{T}}$, which exhibited moderate amounts of phosphatidylmonomethylethanolamine, which was also detected in trace amounts in $R$. mucosa CIP $108268^{\mathrm{T}}$ and $R$. cervicalis CIP $104027^{\mathrm{T}}$ (not shown). Differences among the strains were observed in the presence of several minor spots found close to the origin of spotting, indicating their relatively hydrophilic nature. Since only a single strain of each species was subjected to analysis, the importance of this finding for species identification is so far unclear. It is worth mentioning here that the chromatographic behaviour of the unknown aminolipid AL2 is identical to that of an unknown aminolipid found in Brucella and Ochrobactrum species (Scholz et al., 2008; Kämpfer et al., 2007).

Sequence similarities below $95.0 \%$ of the $16 \mathrm{~S}$ rRNA gene of T. ludipueritiae $170 / 96^{\mathrm{T}}$ with $R$. gilardii subsp. gilardii CIP $104026^{\mathrm{T}}$, R. gilardii subsp. rosea CIP $108267^{\mathrm{T}}$ and $R$. mucosa CIP $108268^{\mathrm{T}}$, the core of the genus, since it

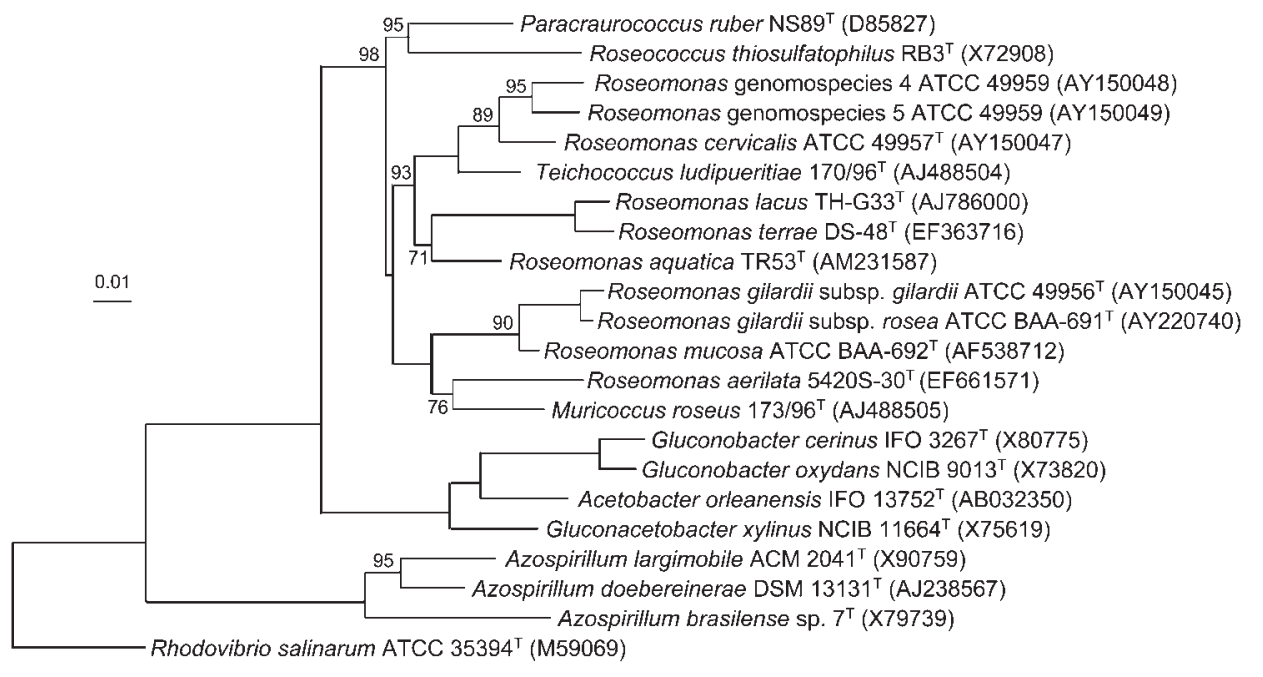

Fig. 1. Phylogenetic tree, based on neighbour-joining of the $16 \mathrm{~S}$ rRNA gene sequence, showing the positions of Teichococcus ludipueritiae, Muricoccus roseus, species of Roseomonas and other closely related bacterial species. Sequence accession numbers used are shown in parentheses. Bootstrap values higher than $50 \%$ are indicated at branch points. Rhodovibrio salinarum ATCC $35394^{\top}$ was used as the outgroup. Bar, $1 \%$ sequence divergence. 
contains the type strain of the type species, suggest that it should not be placed in the genus Roseomonas and that $R$. cervicalis CIP $104027^{\mathrm{T}}$, its nearest relative, should be reclassified in the genus Teichococcus. However, we could not detect any significant phenotypic traits that would support this reclassification. In order to create a phylogeny reflecting taxonomy and considering homogeneity in phenotypic traits, especially in respect of more conserved characteristics such as major polar lipids and polyamine patterns, we propose the transfer of the species Teichococcus ludipueritiae to the genus Roseomonas as Roseomonas ludipueritiae comb. nov. and Muricoccus roseus as Roseomonas rosea comb. nov. Table 1 shows some features that permit the differentiation of these two species from other Roseomonas species.

\section{Emended description of the genus Roseomonas Rins et al. 1998}

In addition to the characteristics listed by Rihs et al. (1993), members of the genus exhibit a polar lipid profile exhibiting major to moderate amounts of diphosphatidylglycerol, phosphatidylglycerol, phosphatidylethanolamine, phosphatidylcholine and two unidentified aminolipids (AL1 and AL2). Fatty acid profiles contain alphaproteobacterial characteristic compounds and the rarely encountered fatty acid $\mathrm{C}_{18: 1} 2-\mathrm{OH}$. The polyamine pattern is characterized by the predominant compound spermidine. The type species is Roseomonas gilardii.

\section{Description of Roseomonas ludipueritiae comb. nov.}

Roseomonas ludipueritiae [lu.di.pue.ri'ti.ae. L. n. ludus garden (sic); L. n. pueritia boyhood, childhood, youth; N.L. gen. n. ludipueritiae intended to mean of a kindergarten].

Basonym: Teichococcus ludipueritiae Kämpfer et al. 2003.

The description is the same as that given for Teichococcus ludipueritiae by Kämpfer et al. (2003). The species exhibits the characteristics listed in the emended description of the genus Roseomonas. Other phenotypic features are described in Table 1. The type strain is $170 / 96^{\mathrm{T}}\left(=\mathrm{CIP} 107418^{\mathrm{T}}\right.$ $=$ DSM $14915^{\mathrm{T}}$ ).

\section{Description of Roseomonas rosea comb. nov.}

Roseomonas rosea (ro'se.a. L. fem. adj. rosea rose-coloured, pink).

Basonym: Muricoccus roseus Kämpfer et al. 2003.

The description is the same as that given for Muricoccus roseus by Kämpfer et al. (2003). The species exhibits the characteristics listed in the emended description of the genus Roseomonas. Other phenotypic features are described in Table 1 . The type strain is $173 / 96^{\mathrm{T}}\left(=\mathrm{CIP} 107419^{\mathrm{T}}\right.$ $=$ DSM $14916^{\mathrm{T}}$ ).

\section{Emended description of Roseomonas gilardii Rihs et al. 1998}

In addition to the characteristics listed by Rihs et al. (1993), the species exhibits the characteristics listed in the emended genus description. The type strain is $5424^{\mathrm{T}}$ (=ATCC $49956^{\mathrm{T}}=$ CCUG $33005^{\mathrm{T}}=$ CIP $104026^{\mathrm{T}}$ ).

\section{Emended description of Roseomonas gilardii subsp. gilardii Rihs et al. 1998}

In addition to the characteristics listed by Rihs et al. (1993) and Han et al. (2003), the subspecies exhibits the characteristics listed in the emended genus description. The type strain is $5424^{\mathrm{T}}\left(=\right.$ ATCC $49956^{\mathrm{T}}=$ CCUG $33005^{\mathrm{T}}$ $=$ CIP $104026^{\mathrm{T}}$ ).

\section{Emended description of Roseomonas gilardii subsp. rosea Han et al. 2003}

In addition to the characteristics listed by Han et al. (2003), the subspecies exhibits the characteristics listed in the emended genus description. The type strain is strain MDA5605 ${ }^{\mathrm{T}}\left(=\right.$ ATCC BAA-691 $1^{\mathrm{T}}=$ NCTC $\left.13290^{\mathrm{T}}\right)$.

\section{Emended description of Roseomonas aquatica Gallego et al. 2006}

In addition to the characteristics listed by Gallego et al. (2006), the species exhibits the characteristics listed in the emended genus description. The type strain is $\mathrm{TR} 53^{\mathrm{T}}$ $\left(=\right.$ CECT $7131^{\mathrm{T}}=$ JCM $\left.13556^{\mathrm{T}}\right)$.

\section{Emended description of Roseomonas cervicalis Rihs et al. 1998}

In addition to the characteristics listed by Rihs et al. (1993) the species exhibits the characteristics listed in the emended genus description. The type strain is $\mathrm{E} 7107^{\mathrm{T}}$ (=ATCC $49957^{\mathrm{T}}=$ CIP $104027^{\mathrm{T}}$ ).

\section{Emended description of Roseomonas mucosa Han et al. 2003}

In addition to the characteristics listed by Han et al. (2003), the species exhibits the characteristics listed in the emended genus description. The type strain is $\operatorname{MDA}_{52} 7^{\mathrm{T}} \quad\left(=\right.$ ATCC $\quad$ BAA- $692^{\mathrm{T}} \quad=$ CCUG $48654^{\mathrm{T}}$ $=$ NCTC $\left.13291^{\mathrm{T}}\right)$.

\section{Emended description of Roseomonas lacus Jiang et al. 2006}

In addition to the characteristics listed by Jiang et al. (2006), the species exhibits the characteristics listed in the emended genus description. The type strain is TH-G33 ${ }^{\mathrm{T}}$ $\left(=\right.$ CGMCC $1.3617^{\mathrm{T}}=$ JCM $\left.13283^{\mathrm{T}}\right)$. 


\section{Acknowledgements}

This study was supported by grants from the Spanish Ministerio de Educación y Ciencia (project BIO2006-006927) and from the Junta de Andalucía (project P06-CVI-01829).

\section{References}

Busse, H.-J. \& Auling, G. (1988). Polyamine pattern as a chemotaxonomic marker within the Proteobacteria. Syst Appl Microbiol 11, 1-8.

Chun, J., Lee, J.-H., Jung, Y., Kim, M., Kim, S., Kim, B. K. \& Lim, Y. W. (2007). EzTaxon: a web-based tool for the identification of prokaryotes based on $16 \mathrm{~S}$ ribosomal RNA gene sequences. Int J Syst Evol Microbiol 57, 2259-2261.

Gallego, V., Sánchez-Porro, C., García, M. T. \& Ventosa, A. (2006). Roseomonas aquatica sp. nov., isolated from drinking water. Int J Syst Evol Microbiol 56, 2291-2295.

Han, X. Y., Pham, A. S., Tarrand, J. J., Rolston, K. V., Helsel, L. O. \& Levett, P. N. (2003). Bacteriologic characterization of 36 strains of Roseomonas species and proposal of Roseomonas mucosa sp. nov. and Roseomonas gilardii subsp. rosea subsp. nov. Am J Clin Pathol 120, 256-264.

Helsel, L. O., Hollis, D. G., Steigerwalt, A. G. \& Lewett, P. N. (2006). Reclassification of Roseomonas fauriae Rihs et al. 1998 as a later heterotypic synonym of Azospirillum brasilense Tarrand et al. 1979. Int J Syst Evol Microbiol 56, 2753-2755.

Jiang, C. Y., Dai, X., Wang, B. J., Zhou, Y. G. \& Liu, S. J. (2006). Roseomonas lacus sp. nov., isolated from freshwater lake sediment. Int J Syst Evol Microbiol 56, 25-28.

Kämpfer, P. \& Kroppenstedt, R. M. (1996). Numerical analysis of fatty acid patterns of coryneform bacteria and related taxa. Can J Microbiol 42, 989-1005.

Kämpfer, P., Andersson, M. A., Jäckel, U. \& Salkinoja-Salonen, M. (2003). Teichococcus ludipueritiae gen. nov. sp. nov., and Muricoccus roseus gen. nov. sp. nov. representing two new genera of the $\alpha-1$ subclass of the Proteobacteria. Syst Appl Microbiol 26, 23-29.

Kämpfer, P., Scholz, H. C., Huber, B., Falsen, E. \& Busse, H.-J. (2007). Ochrobactrum haematophilum sp. nov. and Ochrobactrum pseudogrignonense sp. nov., isolated from human clinical specimens. Int J Syst Evol Microbiol 57, 2513-2518.

Kersters, K., Hinz, K.-H., Hertle, A., Segers, P., Lievens, A., Siegmann, O. \& De Ley, J. (1984). Bordetella avium sp. nov., isolated from the respiratory tracts of turkeys and other birds. Int $J$ Syst Bacteriol 34, 56-70.

Ludwig, W., Strunk, O., Klugbauer, S., Klugbauer, N., Weizenernegger, M., Neumaier, J., Bachleitner, M. \& Schleifer, K.-H. (1998). Bacterial phylogeny based on comparative sequence analysis. Electrophoresis 19, 554-568.

Ludwig, W., Strunk, O., Westram, R., Richter, L., Meier, H., Yadhukumar, Buchner, A., Lai, T., Steppi, S. \& other authors (2004). ARB: a software environment for sequence data. Nucleic Acids Res 32, 1363-1371.

Rihs, J. D., Brenner, D. J., Weaver, R. E., Steigerwalt, A. G., Hollis, D. G. \& Yu, V. L. (1993). Roseomonas, a new genus associated with bacteremia and other human infections. J Clin Microbiol 31, 32753278.

Rihs, J. D., Brenner, D. J., Weaver, R. E., Steigerwalt, A. G., Hollis, D. G. \& Yu, V. L. (1998). Roseomonas gen. nov. In Validation of the Publication of New Names and New Combinations Previously Effectively Published Outside the IJSB, List no. 65. Int J Syst Bacteriol 48, 627.

Scholz, H. C., Hubalek, Z., Sedláček, I., Vergnaud, G., Tomaso, H., Al Dahouk, S., Melzer, F., Kämpfer, P., Neubauer, H. \& other authors (2008). Brucella microti sp. nov., isolated from the common vole Microtus arvalis. Int J Syst Evol Microbiol 58, 375-382.

Stolz, A., Busse, H.-J. \& Kämpfer, P. (2007). Pseudomonas knackmussii sp. nov. Int J Syst Evol Microbiol 57, 572-576.

Yoon, J. H., Kang, S. J., Oh, H. W. \& Oh, T. K. (2007). Roseomonas terrae sp. nov. Int J Syst Evol Microbiol 57, 2485-2488. 